\title{
Зародження та становлення театрального мистецтва в Маріуполі протягом XIX ст.
}

\author{
Демідко О. О., Маріупольський державний університет
}

Досліджено становлення театрального мистецтва в Маріуполі. Зроблено історичний екскурс, що дозволило проаналізувати та визначити особливості театральної культури Маріуполя протягом ХІХ ст. Виявлено, що протягом 40-х років XIX ст. вагомим чинником формування театральної культури в Маріуполі стає наявність мандрівних (пересувних) труп. Охарактеризовано виникнення першої професійної трупи в місті, загальні тенденції розвитку маріупольського театру, а також проаналізовано наявні проблеми в театральній культурі міста у зазначений період. 3'ясовано, що особливе місце в театральному житті Маріуполя наприкінці XIX ст. посідав український музично-драматичний театр. Встановлено, що особливостями розвитку театрального мистецтва в Маріуполі в цей період стали постійна наявність у регіоні гастролюючих труп, музично-розважальна спрямованість багатьох вистав та розвиток аматорського руху. Оцінено вплив театрального мистецтва на мешканців міста і встановлено, що серед маріупольців театр користувався великим пошануванням.

Ключові слова: маріупольський театр; антрепренер; «Храм музи Мельпомени; Концертна зала; зимовий театр

\section{The birth and formation of theatrical art in Mariupol during XIX the century}

\section{Demidko O. O., Mariupol State University}

The author explores the history of Mariupol theater in the initial period of its activity. The research allowed to analyze the features of the theatrical life of Mariupol in the initial period of development of the theater. Based on the available literature, the author examined the general trends of formation and development of the theater in Mariupol during XIX century. Scientific interest in the issues of the history of theater as a social phenomenon, regional characteristics of a culture of Ukraine, and rethinking the revival of forgotten pages of artistic life in the regions, the study of their genesis is actively updated in domestic science present.

History of theatrical art in Mariupol began in the mid-19th century, when the city began to appear visiting acting troupe brought into the city entrepreneur Vladimir Vinogradov. Due to the lack of suitable premises performances were held in rented barns, which were often lacking the most basic conditions.

In 1878 Shapovalov created the first professional troupe in Mariupol. It was in 1878 - is considered the founding year of Mariupol theater for many reasons. First, the city created a special space for the theater, and secondly acted ongoing training Mariupol corpse. V. Shapovalov first performances were a great success, but in spite of this at the end of the season was an entrepreneur in a very difficult financial position.

In 1887 the opening of the theater building, built at the expense of the same Basil Shapovalov, which was called the Concert Hall, and later - Winter Theatre.Opening of the Hall was a great event in the life of the city, wrote about him in the metropolitan and provincial newspapers. Hall has begun to attract the best in the seaside town theater forces of Ukraine and Russia. In gratitude, the city government released V. Shapovalov from tax for a concert hall for 10 years.

Thus, the formation and development of creative theater culture Mariupol began in the mid XIX century. When the city appeared first permanent acting troupe. Due to lack of space performances were held in rented storage rooms, which often did not have basic conditions. In 1878, the city established the first local company, consisting of professional actors. After the opening of the concert hall V. Shapovalov collective creative work was aimed at staging performances of Russian and Ukrainian classics. Mariupol theater has always remained faithful to the traditions of the past, and maintaining the level of excellence of its productions.

Keywords: Mariupol theater impresario; «Temple of the Muses Melpomene»; a concert hall; a winter theater

\section{Зарождение и становление театрального искусства в Мариуполе в течение XIX в.}

\section{Демидко О. А., Мариупольский государственный университет}

Исследовано становление театрального искусства в Мариуполе. Сделан исторический экскурс, что позволило проанализировать и определить особенности театральной культуры Мариуполя в течение ХІХ в. Выявлено, что в течение 40-х годов XIX в. весомым фактором формирования театральной культуры в Мариуполе становится наличие гастролирующих трупп. Охарактеризовано возникновения первой профессиональной труппы в городе, общие тенденции развития мариупольского театра, а также проанализированы существующие проблемы в театральной культуре города в указанный период. Выяснено, что особое место в театральной жизни Мариуполя в 
конце XIX в. занимал украинский музыкально-драматический театр. Установлено, что особенностями развития театрального искусства в Мариуполе в этот период стали постоянное наличие в регионе гастролирующих трупп, музыкально-развлекательная направленность многих спектаклей и развитие любительского движения. Оценено влияние театрального искусства на жителей города и установлено, что среди мариупольцев театр пользовался большим уважением.

Ключевые слова: мариупольский театр; антрепренер; «Храм музы Мельпомены»; концертный зал; зимний театр

\section{Постановка проблеми.}

$\mathrm{B}$ ивчення регіональних традицій театрального мистецтва залишається невичерпним об'єктом для дослідження духовної культури суспільства. На сьогоднішній день театральне життя Маріуполя не висвітлено як самобутній мистецький феномен, потребує осмислення 3 позицій розуміння його як культурної цілісності. Протягом XIX ст. відбулося формування, творче становлення та пошук власного шляху у мистецтві своєрідної театральної культури міста.

Регіональна проекція, за допомогою якої розглядається театральне мистецтво Маріуполя в цілісному культурно-історичному аспекті соціального, духовного, художнього, мистецького життя регіону кінця XIX - початку XX ст., уможливлює сучасну інтерпретацію культури України в іiі регіональних вимірах.

Аналіз досліджень і публікацій.

Загальновизаною є думка про те, що першим історіографом театру в Маріуполі був викладач давніх мов Олександрійської чоловічої гімназії О. Петрашевський, який написав нарис, що вміщений у збірці «Мариуполь и его окрестности: отчет об учебных экскурсиях Мариупольской Александровской гимназии» від 1892 р. У ньому розглянуто численні проблеми, пов'язані з формуванням театральної культури Маріуполя у XIX ст. У роботі радянського бібліографа, бібліотекознавця та літературознавця Ю. Меженка «Життя артистки» висвітлюється діяльність видатної української акторки Любові Павлівни Ліницької у трупі В. Шаповалова.

Формування і становлення театральної культури Маріуполя досліджували краєзнавці А. Іванов [1], Л. Чуприк [9], Л. Яруцький [10-13]. Незважаючи на наявність праць, присвячених розвитку театрального мистецтва в Маріуполі, до цього часу відсутнє спеціальне історичне дослідження, присвячене означеній проблематиці. Більшість публікацій представлена критичними рецензіями на сторінках місцевої періодичної преси. Цей матеріал потребує систематизації, осмислення і введення до наукового обігу в якості фактологічної бази.

Мета дослідження - проаналізувати зародження та становлення театрального мистецтва в Маріуполі протягом XIX ст.

Виклад основного матеріалу.

Складні умови історичного та соціально- економічного життя українського народу XIX та початку XX століть позначалися на культурному розвитку мешканців Приазов'я. Проте в таких складних умовах серед жителів Маріуполя відчувався потяг до мандрівного дійства. Тривалий час у регіоні не було жодного стаціонарного театру.

Протягом 40-х років XIX ст. вагомим чинником формування театральної культури в Маріуполі стає наявність мандрівних (пересувних) труп. Так, у 1847 р. трупа антрепренера В. Виноградова, згодом актора петербурзького Олександрінського театру, прибувши до Маріуполя, відкрила перший театральний сезон. Спочатку вистави мешканцям міста здалися дивними і незрозумілими. Суспільство, не виховане на театральному мистецтві, не могло одразу відповідно реагувати на культурні нововведення. Але, незважаючи на це, трупа В. Виноградова мала в Маріуполі успіх [3, с. 291]. Через відсутність театрального приміщення вистави можна було побачити в кам'яній коморі на Катерининській вулиці, що належала купцеві М. Логофетову. Репертуар першого колективу, який відвідав Маріуполь, встановити не вдалося. Відомо, що в той час на сценах провінційних театрів найчастіше ставили твори В. Шекспіра, І. Шиллера, М. Гоголя, О. Грибоєдова [3, с. 293].

Перший театральний сезон був настільки успішним, що драматичні трупи стали частіше відвідувати Маріуполь. За кілька років театр у Маріуполі став центром культури міського життя. Цим скористався маріупольський купець $\mathrm{H}$. Попов, який свою дерев'яну комору нашвидку переобладнав на театральне приміщення і дав йому пишну назву: «Храм музи Мельпомени» [11, c. 176]. У театрі були обладнані невелика сцена, місце для оркестру, партер з декількох рядів лав і галерея в кінці зали. У будівлі могло розміститися не більше 30-40 осіб. Місцеві мешканці відвідували театр дуже охоче і щедро винагороджували різними подарунками тих антрепренерів і акторів, які особливо їм подобалися. «Храм музи Мельпомени» приносив чимало незручностей як акторам, так і публіці, проте на його сцені грали цікаві трупи, відомі на той час усій Російській імперії. Отримуючи дуже часто від різних антрепренерів пропозиції здати їм в аренду для драматичних вистав «Храм Мельпомени», Н. Попов вирішив удосконалити театр: розширив сцену, влаштував ряд лож, а галерею $з$ окремим входом розмістив нагорі. Однак, як зауважує перший історіограф те- 
атру в Маріуполі О. Петрашевський, побудований «Храм музи Мельпомени» був далеким від свого справжнього «типу», але порівняно зі старим театром він був дуже зручним і красивим». У бенефісні дні театр приносив до 300 руб. прибутку [3, c. 292 ].

Поступово Маріуполь набуває популярності театрального міста, яке охоче відвідували професійні трупи. У 1868 р. в місто прибули одночасно дві трупи - Пілоні і Міодушевського. Трупа Пілоні грала в старому театрі Н. Попова, а для трупи Міодушевського акторам вдалося умовити місцевого мешканця В. Айналова обладнати під театр свою комору на Катерининській вулиці. На той час маріупольці надавали перевагу трагедіям, драмам та малоросійським п’єсам. Театр В. Айналова мав неабияку сцену, зручні, оббиті червоним сукном місця для публіки, ярус лож і галерею. Кореспондент журналу «Артист», одного 3 провідних видань театральної періодики останньої третини XIX ст. в Російській імперії, повідомляв: «На сцені нового театру найбільший успіх мала провінційна артистка Жданова, у якої в Маріуполі була велика кількість шанувальників. Користувався любов'ю публіки у новому театрі й актор малоросійських ролей Любимов-Деркач, у той час як у старому театрі успіхом користувався трагік Александров» [4, с 191].

Отже, одночасно в Маріуполі грали дві театральні трупи і жодна з них не залишилася в збитку. І це при тому, що кількість мешканців у місті в той час становила 7644 особи [11, с. 178].

Після закінчення сезону і з від'їдом трупи Міодушевского з Маріуполя В. Айналов зруйнував театр і натомість побудував торгові лавки [4, c. 191].

Згодом Н. Попов продав свій театр Кіоцце, а той своєю чергою - I. Деспоту. У театрі І. Деспота видатним антрепренером був місцевий громадянин В. Шаповалов (1845-1897) [3 , с. 294]. У 1878 p. він створив першу професійну трупу в Маріуполі. Цей факт підтверджують відомості першого номеру щомісячного журналу з питань драматургії і сценічного мистецтва «Театральна бібліотека». У цьому виданні вказувалося, що в 1878 р. в Маріуполі «під управлінням В. Шаповалова» були здійснені 22 постановки, що може свідчити про роботу професійної трупи в місті [12, с. 4]. Театральний сезон розпочався восени 1877 р., але саме в 1878 p. було збудоване спеціальне приміщення для театру і почала діяти постійна професійна маріупольська трупа. Зважаючи на це, ми вважаємо датою заснування маріупольського театру саме 1878 рік.

Василь Леонтійович Шаповалов був людиною цілеспрямованою, пристрасно закоханою в театр. Саме ця пристрасть до мистецтва підштовхнула його на ризикований шлях театрального антрепре- нера. В. Шаповалов був не тільки антрепренером, але й талановитим актором, режисером, вихователем та організатором театрального коллективу, він здійснив постановку семи драм - трьох-, чотирьох- і п’яти-актів [9, с. 4]. Маріупольський глядач побачив такі вистави, як «Російське весілля», «Царева наречена», «Людина, яка сміється», слухав триактну оперу «Фауст навиворіт», а сміялися мешканці міста під час чотириактного водевілю «Волоцюга». Успіхом користувалися також одноактні оперети. Всього в 1878 р. В. Шаповаловим було здійснено 22 вистави, що є значним досягненням для початкового періоду діяльності театру $[11$, c. 181$]$.

Наприкінці XIX ст. набуває розвитку аматорський рух у регіоні. На той час аматорський театр в Україні існував поряд із професійним і був одним із важливих атрибутів національно-культурного відродження. Важливою подією стало створення Маріупольського драматично-музичного товариства у 1884 р. під керівництвом освіченого діяча Е. Батієвського. Члени товариства здійснювали постановки аматорських вистав, влаштовували концерти, сприяли естетичному вихованню мешканців міста [3, с. 297].

У 1885 р. В. Шаповалов ліквідує свою торговельну справу і вирішує побудувати приміщення театру власним коштом. Попри фінансові труднощі та завдяки наполегливій праці, В. Шаповалов втілив у життя свою мрію.

У 1887 р. Василь Леонтійович закінчив будівництво театру на 800 місць із буфетом, фойє, касами та назвав його «Концертною залою». Серед маріупольців приміщення називали «Зимовим театром». У залі була велика сцена, для якої В. Шаповалов замовив гарні декорації. Водночас були зроблені зручні, пронумеровані сидіння для публіки, особливе, відокремлене від глядачів, місце для оркестру. Театральне приміщення В. Шаповалова було безпечним: до глядацької зали вели широкі двері, в самій залі вихід розташовувався 3 лівого боку. По кутах залу милувалися 4 ложі, 3 них одна - «театральна» [3, с. 295].

Концертну залу урочисто відкрили 8 листопада 1887 р. прем’єрою «Ревізора» М. Гоголя. При переповненій залі В. Шаповалов 3 великим успіхом зіграв роль Городничого [2, с. 127]. Відкриття нового театрального приміщення стало великою подією в культурному житті міста, про нього писали в столичних і провінційних газетах Катеринослава, Ростова, Харкова, Новочеркаська, Таганрогу. «Пан Шаповалов збудував прекрасну Концертну залу», - зазначали «Екатеринославские губернские ведомости». «Обширна», «зручна», «містка», «прекрасна» - такими епітетами нагороджували газети Концертну залу В. Шаповалова. Після побудови нового театру до Приазов’я 
були залучені кращі театральні сили України та Росіï. На знак подяки міська влада звільнила В. Шаповалова від сплати податку за Концертну залу на 10 років [9, с. 5].

При повному зборі тепер театр давав тисячу рублів прибутку [3, с. 191]. Отже, квиток коштував не менше рубля, і найбідніші верстви населення не могли дозволити собі таку розкіш - відвідати виставу. I все ж таки Концертна зала В. Шаповалова була демократичною - ii відвідувала не тільки місцева інтелігенція, тоді ще дуже нечисленна, не тільки багаті купці і заможні міщани. В. Шаповалов демонстрував землякам кращі сучасні вистави, запрошуючи до Маріуполя відомих гастролерів. У першому сезоні (з 8 листопада 1887 р. до 6 березня 1888 р.) маріупольці познайомилися 3 мистецтвом талановитих акторів В. Андрєєва-Бурлака, М. Глєбової, М. Іванова-Козельського. Збори були «більш ніж задовільними». Більшість антрепренерів України у тому сезоні зазнали невдач, на відміну від В. Шаповалова, який «залишився задоволений місцевою публікою». Підводячи підсумки зимового сезону, «Екатеринославские губернские ведомости» писали 26 березня 1888 р.: «Маріуполь - місто вельми інтелігентне, в якому мистецтво цінують насправді» [11, с. 194].

Василь Леонтійович умів розгледіти й оцінити талановитого актора. У трупі В. Шаповалова 3 1888 р. почало працювати подружжя Загорських - Іван Оникійович та Любов Павлівна (Ліницька). В. Шаповалову належить заслуга першовідкривача таланту видатної української акторки Любові Павлівни Ліницької, котра грала в російських та українських виставах, але перевагу надавала останнім. Найбільший успіх вона мала у п'єсах: «Наталка Полтавка», «Назар Стодоля», «Невільник», «Шельменко-денщик», «Сватання на Гончарівці». Бібліограф і літературознавець Ю. Меженко зазначав: «У трупі Шаповалова Ліницька на перших ролях і має бенефіс. У неї є власний сценічний гардероб» [5, с. 21]. Через рік (у 1889му році) подружжя Загорських поїхало до М. Кропивницького, визнаного корифея української культури, який Івана Оникійовича, чия акторська слава була на той час вже досить гучною, взяв у свою трупу відразу ж, а Любов Павлівну - після випробувального терміну [6, с. 35]. Отже, деякі маріупольські актори були запрошені в трупу М. Кропивницького, творця реалістичного українського театру, що слугувало найкращою атестацією В. Шаповалову як режисеру i організатору театральної справи [9, с. 4].

Дослідник маріупольського театру А. Іванов зазначив, що «з усієї трупи глядачі виділили лише чотирьох акторів: I. Загорського, якому особливо вдавався український репертуар; Н. Абрамову, О. Вікторова і самого В. Шаповалова (він добре грав Жака Паганеля). Талановитим актором був О. Вікторов, який не тільки грав, але і виступав у якості автора. Так, наприклад, для свого бенефісу О. Вікторов поставив власну оперетку «Українська ніч», що викликала бурхливі оплески» [1, с. 4].

Особливе місце в театральному житті Mapiyполя наприкінці XIX ст. посідав український музично-драматичний театр. Гастролі великих майстрів української сцени М. Кропивницького, П. Саксаганського, I. Карпенка-Карого, М. Садовської-Барілотті дали можливість городянам ознайомитися 3 національною театральною драматургією. Популярністю в Маріуполі користувались вистави «Наталка Полтавка», «Запорожець за Дунаєм», «Сватання на Гончарівці», «Доки сонце зійде, роса очі виїсть», «Наймичка». На сцені концертної зали грали А. Рютчі, Я. Козельський, Л. Манько та ін. [9, с. 7]. Важливим є те, що «Товариство російсько-малоросійських артистів» під керівництвом П. Саксаганського першим містом для своїх виступів обрало Катеринослав, а другим - Маріуполь.

У спогадах видатного українського актора, peжисера і драматурга П. Саксаганського зазначається, що трупа під його керівництвом почала вистави в Маріуполі навесні 1889 р. [7, с. 142]. Звісно, популярністю серед маріупольців користувалися виступи I. Карпенка-Карого, П. Саксаганського та їхньої сестри М. Садовської-Барілотті. Своїм соковитим, красивого тембру сопрано тепло і задушевно виконувала вона українські народні пісні, була незрівнянною в ролі Наталки Полтавки. Успіхом серед маріупольців користувався й Д. Мова, чоловік Марії Карпівни. Талановитий драматичний актор, він $з$ дружиною складав чудовий дует у «Наталці Полтавці», в «Запорожці за Дунаєм», у «Сватанні на Гончарівці» - у всіх спектаклях «Товариства» [11, с. 209].

У Музеї театрального, музичного та кіномистецтва України зберігається годинник із лаконічним написом: «Кропивницькому від маріупольців 29.09.1889 р.». Цей подарунок $€$ матеріальним свідченням того, що дійсно в 1889 p. М. Кропивницький виступав у Маріуполі. Так, у 1891 р. в Маріуполі впродовж декількох днів - 3 9 по 14 серпня - гастролювала трупа М. Кропивницького. Збереглися відомості лише про одну виставу «Зайдиголова», в якій М. Кропивницький - автор п'єси - виконав роль Захарки Лободи. Разом із ним виступали такі видатні актори, як Анна Петрівна Затиркевич-Карпінська і Леонід Якович Манько.

27 червня 1892 р. «Товариство» знову приїжджає до Маріуполя. На наступний день гастролі почалися виставою «Безталанна», в якій I. Карпенко-Карий, автор п’єси, виконував роль Івана, 
а П. Саксаганський, режисер-постановник - роль Гната [10, c. 4].

У газеті «Приазовский край» від 22 липня 1892 р. повідомлялося: «...15 липня відбувся в Маріуполі останній спектакль малоросів «Товариства» П. Саксаганського. «Товариство», за винятком П. Саксаганського та I. Карпенка-Карого, залишилося ще в Маріуполі на кілька вистав. 16 липня трупа «Товариства» поставила концерт-виставу за участю Л. Ліницької на користь чоловічого і жіночого хору та танцюристів» [8, с. 3]. Автор кореспонденції не випадково наголосив на участі у концерті-виставі Л. Ліницької: маріупольці пам'ятали Любов Павлівну і пишалися тим, що свій блискучий шлях актриси вона розпочала саме в їхньому місті.

Завдяки зростанню театральної слави міста влітку 1889 р. маріупольці вперше познайомилися зі справжньою оперою. У місті виступила трупа під керівництвом С. Буховецького. Опера «Життя за царя», вперше поставлена в Маріуполі, пройшла при повних зборах. На останньому спектаклі «Гугеноти» публіка не знала, як і чим висловити свій захват: квіти, бурхливі оплески, подяки акторам. 3 червня того ж року відзначали успіх «Аїди» Дж. Верді. А в 1892 р. Маріуполь відвідала оперна трупа С. Черкасова. Вона поставила 6 опер [3, с. 296].

\section{Висновки.}

Таким чином, творче становлення та розвиток театрального мистецтва Маріуполя почався в середині XIX ст., коли в місті з'являлися перші заїжджі акторські трупи. Через відсутність відповідного приміщення спектаклі влаштовувалися в орендованих коморах, в яких часто не було найелементарніших умов. У 1878 р. в Маріуполі була створена перша місцева трупа, що складалася 3 професійних акторів. Музично-розважальна спрямованість багатьох вистав, постановка спектаклів української, російської та іноземної класики, розвиток аматорського руху та активна благодійна діяльність акторів сприяли зростанню глядацької активності жителів Маріуполя. 3 кінця XIX ст. особливе місце в репертуарі посідає українська класика. Серед маріупольців театр користувався великим пошануванням. Провідними жанрами театрального мистецтва в регіоні стали музичний (опера, водевіль, музична драма і вокальні концерти) та драматичний (трагедія, комедія, драма). Маріупольський театр завжди залишався вірний традиціям минулого, зберігаючи рівень і майстерність своїх постановок.

\section{БІБІЛІОГРАФІЧНІ ПОСИЛАННЯ}

1. Иванов А. Театр у нас - капитальнейшее развлечение / А. Иванов // Приазовский рабочий. - 1968. - № 109. C. 4.

2. Божко Р. П. Мариуполь и его окрестности: взгляд из XXI века / Р. П. Божко, Т. Ю. Були, Н. Н. Гашененко и др. - Мариуполь: «Рената», 2008. - 428 с.

3. Мариуполь и его окрестности / Издание почетного попечителя Д. А.Харджаева. - Мариуполь: Типо-Литография А. А. Франтова, 1892. - 461 с.

4. Мариуполь (от нашего кореспондента) [Из Провинциальных корреспонденций] // Артист: Журнал изящных искусств и литературы. - 1893. - № 26. - С. 191.

5. Меженко Ю. О. Життя артистки / Ю. О. Меженко. - Київ: Держ. видавництво образотворчого мистецтва і музичної літ., 1957. - С. 3-99.

6. Некролог. И. А. Загорский // Киевская старина. - 1904. - № 6. - С. 34-35.

7. Саксаганський П. По шляху життя: мемуари (П. К. Тобілевич) / П. Саксаганський. - Харків: Держлітвидав, 1935. - 230 c.

8. Спектакль товарищества П. Саксаганского // Приазовский край. - 1892. - № 157. - С. 3.

9. Чуприк Л. Н. Научная справка из истории Мариупольського театра / Л. Н. Чуприк. - Мариуполь: Архив Мариупольського краеведческого музея, 1998. - 28 с.

10. Яруцкий Л. Д. Корифеи украинской культуры в Мариуполе. Биография нашего театра / Л. Д. Яруцкий // Приазовский рабочий. - 1978. - № 120. - С. 4.

11. Яруцкий Л. Д. Мариупольская старина: Рассказы краеведа / Л. Д. Яруцкий. - М.: Советский списатель, 1991. -432 c.

12. Яруцкий Л. Рубежный год / Л. Яруцкий // Приазовский рабочий. - 1978. - № 57. - С. 4.

13. Яруцкий Л. Д. Старейший в Украине (Из истории Донецкого обласного драматического театра) / Л. Д. Яруцкий. - Мариуполь: «Рената», 1998. - 104 с.

\section{REFERENCES}

1. Ivanov, A. (1968). Teatr u nas - kapitalneyshee razvlechenie [The theater we have - the most fun]. Priazovsk Worker [in Russian].

2. Bozhko, R.P, Buli, T.Yu., \& Gashenenko, N.N. (2008). Mariupol i ego okrestnosti: vzglyad iz XXI veka [Mariupol and its environs: a view from the 21st century]. Mariupol: «Renata» [in Russian].

3. Mariupol $i$ ego okrestnosti. Izdanie pochetnogo popechitelya D.A.Hardzhaeva [Mariupol and its surroundings. 
Publication of the Honorary Trustee DA Khardzhayev]. (1892). Mariupol: Typo-lithography AA Frantova [in Russian].

4. Mariupol (ot nashego korespondenta). Iz Provintsialnyih korrespondentsiy. [Mariupol (from our correspondent). From Provincial Correspondence]. (1893). Artist: Journal of Fine Arts and Literature, 26, 191 [in Russian].

5. Mezhenko, Ju. (1957). O. Zhyttja artystky [The life of the artist]. Kyiv: State Publishing House of Fine Arts and Music Literature [in Ukrainian].

6. Nekrolog. I. A. Zagorskiy [Obituary. I. A. Zagorsky]. (1904). Kievskaya starina, 6, 34-35 [in Russian].

7. Saksaghansjkyj, P. (1935). Po shljakhu zhyttja: memuary (P. K. Tobilevych) [By the way of life: memoir (P. K Tobilevich)]. Kharkiv: State Council issued [in Ukrainian].

8. Spektakl tovarischestva P. Saksaganskogo [Performance of the partnership of P. Saksaganskogo]. (1892). Priazovsk Region, 157, 3 [in Russian].

9. Chuprik, L.N. [1998]. Nauchnaya spravka iz istorii Mariupolskogo teatra [A scientific reference from the history of the Mariupol Theater]. Mariupol: Archive of the Mariupol local history museum [in Russian].

10. Yarutskiy, L.D. (1978). Korifei ukrainskoy kulturyi v Mariupole. Biografiya nashego teatra [Coryphaeus of Ukrainian culture in Mariupol. Biography of our theater]. Priazovsk Worker, 120, 4 [in Russian].

11. Yarutskiy, LD. (1991). Mariupolskaya starina: Rasskazyi kraeveda [Mariupol antiquities: Stories of local lore]. Moscow: Soviet listener [in Russian].

12. Yarutskiy, L. (1978). Rubezhnyiy god [Boundary year]. Priazovsk Worker, 57, 4 [in Russian].

13. Yarutskiy, L.D. (1998). Stareyshiy v Ukraine (Iz istorii Donetskogo oblasnogo dramaticheskogo teatra) [The oldest in Ukraine (From the history of the Donetsk Regional Dramatic Theater)]. Mariupol: Renata [in Russian].

\author{
Демідко Ольга Олександрівна \\ Аспірант \\ Маріупольський державний університет \\ 87500, Маріуполь, пр. Будівельників, 129а
}

\title{
Demidko Olha 0.
}

Post-graduate student

Mariupol State University

129a , Budivelnykiv Ave., Mariupol, 87500, Ukraine

ORCID: 0000-0003-2605-5934 Email: demidko.olga1991@gmail.com

Цитування: Демідко О. О. Зародження та становлення театрального мистецтва в Маріуполі протягом XIX ст. / О. О. Демідко // Науково-теоретичний альманах «Грані». - 2018. - Т. 21. - № 3. - С. 70-75.

Citation: Demidko, O.O. (2018). Zarodzhennia ta stanovlennia teatralnoho mystetstva v Mariupoli protiahom XIX st. [The birth and formation of theatrical art in Mariupol during XIX the century]. Scientific and theoretical almanac «Grani», 21(3), 70-75. 